\title{
Pर̌EHLEDOVÁ STǍ̌
}

\section{Ke kořenům sociálně psychologického modelu sociální stratifikace ${ }^{1}$}

\author{
PETR MATĚJŮ* \\ Sociologický ústav AVČR \\ a Anglo-American College, Praha
}

\section{The Roots of the Socio-Psychological Model of Social Stratification}

\begin{abstract}
This article, published in connection with the recent death of Otis Dudley Duncan (16 November 2004), sets out to provide a critical summary of the development - from its beginnings in the 1960s up to its final revision and modification in 1983 - of the socio-psychological model of the status attainment process. The article not only looks at the classic model of the social stratification process of Blau and Duncan, but also examines the influence of one of the founders of the socio-psychological branch of the study of social stratification, W. H. Sewell. Special attention is devoted to the development of the so-called Wisconsin model, primarily the work of William H. Sewell and his student, Robert M. Hauser, who, while as a student of Duncan also, considerably contributed to the use of structural modelling in sociology. The article concludes with a brief discussion of the main critical reactions to the socio-psychological model emphasising the 'allocational' paradigm of interpretation of the reproduction of social inequalities. The article should primarily help students of sociology gain an orientation in the massive amount of often poorly accessible literature on one of the most cited of sociology's 'products'.
\end{abstract}

Sociologický časopis/Czech Sociological Review, 2005, Vol. 41, No. 1: 7-30

Před třemi lety zemřel ve věku 91 let William Hamilton Sewell, jeden z předních amerických sociologů, jehož jméno je spojováno v prvé řadě se sociálně psychologickým modelem sociální stratifikace [viz např. Sewell 1961, 1963; Hauser, Sewell 1976, 1984, 1985, 1986; Sewell, Hauser 1975, 1980]. ${ }^{2}$ Jeho představa o mezigenerační transmisi sociálně-ekonomického statusu a o úloze rodiny a významného sociálního okolí v tomto procesu se však formovala v kontextu diskusí nad známým „zá-

\footnotetext{
* Veškerou korespondenci posílejte na adresu: doc. PhDr. Petr Matějů, Ph.D., Sociologický ústav AV ČR, Jilská 1, 11000 Praha 1, e-mail: mateju@mbox.cesnet.cz.

1 Tato stat́ vznikla v rámci projektu „Ekonomické, sociální a kulturní zdroje vzdělanostních nerovností a determinanty životního úspěchu: první fáze longitudinálního výzkumu“ financovaného z grantu od Grantové agentury České republiky (grant č. 403/03/340) a v rámci výzkumného semináře AAVŠ.

${ }^{2}$ William H. Sewell zemřel ve věku 91 let 24. června 2001 v Madisonu (Wisconsin, USA), kde byl emeritním profesorem sociologie.
}

(C) Sociologický ústav AV ČR, Praha 2005 
kladním modelem sociální stratifikace“, jehož hlavním autorem i propagátorem byl Otis Dudley Duncan [Blau, Duncan 1967], který zemřel na sklonku roku 2004. ${ }^{3}$ Ačkoli ve výuce sociální stratifikace se oběma těmto významným postavám světové sociologie jistě dostává zasloužené pozornosti i u nás, nemohu se zbavit dojmu, že jejich význam pro výzkum sociální stratifikace nebyl v naší sociologii dostatečně oceněn. Úmrtí druhého ze zakladatelů jedné z nejvlivnějších větví výzkumu sociální stratifikace je nepochybně důvodem $\mathrm{k}$ tomu, abychom tuto mezeru zaplnili. Navíc je známo, že otázky, které si oba tito velikáni světové sociologie kladli, a otázky, které vyvolávali u ostatních sociologů, výrazně přispěly $\mathrm{k}$ růstu významu longitudinálních šetření, bez nichž není možné na tyto otázky dát uspokojivé odpovědi. Česká sociologie se na tuto cestu vydává vlastně až nyní. ${ }^{4}$ I to je jistě silný důvod pro to, abychom si připomněli, jaký teoretický diskurs provázel vývoj modelů sociální stratifikace a jakými cestami se ubíralo jejich testování.

Naše sociologie stačila ještě vliv Blau-Duncanova modelu zaznamenat. Šafár [Šafáŕ 1972] replikoval základní model na datech pocházejících z prvního československého stratifikačního výzkumu provedeného v roce 1967 pod vedením P. Machonina [Machonin a kol. 1969]. K problémům spjatým s touto replikou a k otázce, zda Blau-Duncanův model byl nebo nebyl vhodnou reprezentací stratifikačního procesu v Československu na konci šedesátých let, jsem se vyslovil již dřive [Boguszak, Gabal a Matějů 1990]. Hlavní problém ale spočívá v tom, že naše sociologie byla nucena se se světovou sociologií znovu rozejít právě ve chvíli, kdy Blau-Duncanův základní model začal být seriózně diskutován, modifikován a dále rozvijen. Přitom hlavní směr rozvoje modelu vedl $\mathrm{k}$ podstatným modifikacím právě v těch jeho místech, kde selhávala jeho schopnost dobře diferencovat mezi askripcí a meritokratickou selekcí. Právě tato místa modelu jsou ovšem klíčová pro postižení rozdílů mezi zeměmi, které se s větším či menším úspěchem vyvíjely směrem $k$ meritokratickému modelu sociální stratifikace (vyspělé země s tržními ekonomikami a pluralitním politickým systémem), a zeměmi, které se tomuto modelu nejprve vzdalovaly (země tzv. "reálného socialismu“), aby se k němu opět v období transformace začaly pomalu vracet. $\mathrm{V}$ tomto smyslu je tato stat' i pokusem zprostředkovat mladé generaci českých sociologů podstatu debaty, které se ve snaze pochopit povahu proměny sociální stratifikace v období transformace nevyhneme ani my.

\section{Základní model a jeho první modifikace}

Mezi sociology zabývajícími se sociální stratifikací panuje všeobecný konsensus $\mathrm{v}$ tom, že Blau-Duncanův model stratifikačního procesu [Blau, Duncan 1967] měl pro další vývoj studia sociální stratifikace zásadní význam. Přesto by se dnes asi ni-

${ }^{3}$ Otis Dudly Duncan zemřel ve věku 83 let 16. 11. 2004. Před odchodem do důchodu v roce 1987 působil na Kalifornské univerzitě v Santa Barbaře.

4 První rozsáhlý longitudinální projekt byl u nás zahájen až v roce 2003 v návaznosti na mezinárodní výzkumný projekt PISA 2003. 
kdo neodvážil tento model v jeho původní podobě (diagram 1) aplikovat na analýzu jakéhokoli reálného sociálního systému. Důvod je zřejmý. Blau a Duncan svým modelem ukázali cestu, jíz bylo nezbytné se vydat, abychom se přiblížili pochopení procesů a mechanismů ovládajících alokaci jedinců v zaměstnaneckém systému, tj. mechanismů a procesů, jejichž „produkt“ či konečný výsledek zobrazují mobilitní tabulky. ${ }^{5} \mathrm{~V}$ podobě "path-analýzy“, kterou předtím znala prakticky jen genetika, navíc dali sociologům do ruky metodu, která se později stala jedním z nejmocnějších nástrojů kvantitativní analýzy ve společenských vědách (strukturní modelovánî). Blau-Duncanův model byl však př́liš jednoduchý na to, aby bylo možné jej přijmout jako konečné řešení. Ze stejného důvodu, tj. pro jeho jednoduchost, bylo ovšem obtížné tento model jednoduše vyvrátit. Proto byl hned na počátku pojmenován jako „základní model“ („,baseline model“) a byl to samotný Duncan se svými žáky, kdo jako první usiloval o jeho rozšriření.

Blau-Duncanův základní model byl ve skutečnosti hypotézou o převaze univerzalismu a meritokratických principů nad askripcí. Parametry modelu byly pochopitelně interpretovány v intencích této hypotézy. Shrneme-li původní i některé pozdější interpretace modelu, můžeme říci, že základní poznatky, které model přinesl, byly následující:

V procesu dosahování zaměstnaneckého statusu hraje klíčovou roli vzdělání.

Dosažené vzdělání vysvětluje téměř veškerý efekt sociálního původu na zaměstnanecký status respondenta, tj. vliv sociálního původu se realizuje téměř výhradě prostřednictvím vzdělání.

Protože vzdělání je do značné míry nezávislé na rodinném původu, má úsilí o dosažení vyššího vzdělání značný a nezávislý efekt na zaměstnanecký status respondenta.

Rok po vydání "The American Occupational Structure" Duncan základní model interpretuje takto: „Bylo zjištěno, že vzdělání je mocným faktorem zmenšování nerovností v americkém stratifikačním systému, a to i přesto, že do značné míry zprostředkovává efekt sociálního původu na pozdější profesionální dráhu, tj. že slouží rovněž jako kanál mezigeneračního přenosu sociálního statusu“ [Duncan 1968: 21].

Duncan nebyl pochopitelně první, kdo přisoudil vzdělání klíčovou roli ve stratifikačním systému. Sorokin [1927, 1959] považoval vzdělání za hlavní kanál vertikální mobility, to znamená, že škola byla $\mathrm{v}$ jeho pojetí v prvé řadě institucí zajištúuící efektivní sociální selekci a distribuci individuí do sociálních vrstev. Parsons [1959] navíc považoval školu za instituci, ve které probíhá tzv. „pozdější socializace“ (,adolescent socialization“) zdůrazňující sociální normy a hodnoty, mezi nimi pak zejména hodnotu "výkonu“ („achievement”). Tím, že škola adolescenty vy-

\footnotetext{
${ }^{5}$ Studium zaměstnanecké mobility, které do té doby ovládalo stratifikační výzkum [viz například Glass 1956; Rogoff 1953; Lipset \& Bendix 1959 aj.] nanejvýš vedlo ke zjištěním týkajícím se "výsledku“ stratifikačního procesu, tj. již dosažené zaměstnanecké pozice. Samotný proces stratifikace, tj. mechanismy a procesy, které dosažení určité zaměstnanecké pozice zprostředkovávají, byl však pochopitelně mimo dosah studia mobilitních tabulek.
} 


\section{Diagram 1. Základní model - Blau \& Duncan 1967}

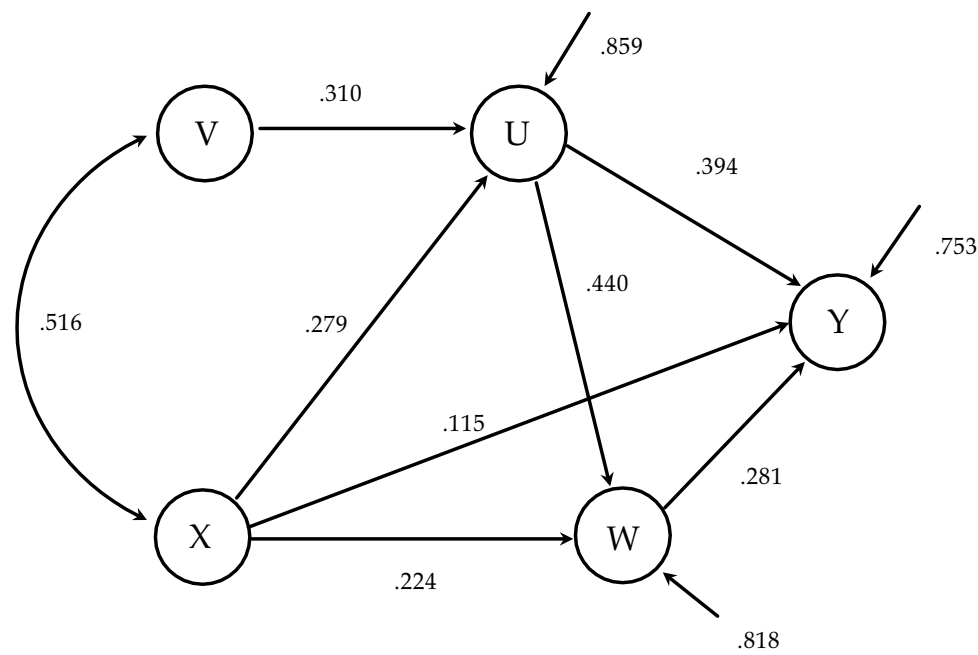

$\mathrm{V}=$ vzdělání otce

$\mathrm{X}=$ zaměstnanecký status otce

U = dosažené vzdělání
$\mathrm{W}=$ zaměstnanecký status $\mathrm{v}$ prvním povolání $\mathrm{Y}=$ zaměstnanecký status $\mathrm{v}$ době šetření

stavuje soutěži a dává jim pocítit důsledky neúspěchu, nejenže provádí potřebnou selekci, což je role školy zdůrazňovaná Sorokinem, ale současně jim vštěpuje normy a hodnoty, na kterých podle Parsonse stojí sociální systém moderní industriální společnosti.

Blau-Duncanův základní model tedy v podstatě potvrdil hypotézy o klíčovém významu školy a školského systému a vzdělání jako „produktu“ těchto institucí vyjádřené v pracích jejich předchůdců. Jeho význam pro další výzkum stratifikačního procesu tím ovšem nekončí. Pro vývoj modelů stratifikačního procesu měl rozhodující význam fakt, že vzdělání se v základním modelu skutečně ukázalo být klíčovým faktorem životního úspěchu, ale přitom se ukázalo, že není nezávislé na sociálním pưvodu. Tím se vzdělání kvalifikovalo jako mediátor mezi sociálním původem a dosaženým zaměstnaneckým statusem. Zcela konsekventně se tedy objevila otázka, zda vzdělání hraje roli mediátoru mezi sociálním původem proto, že distribuce vzdělání je podřízena askriptivním mechanismům (děti pocházející z rodin s vyšším sociálním statusem mají prostě vyšší šanci na dosažení vyššího vzdělání bez ohledu na další faktory), nebo proto, že vzdělávací systém je sociální institucí, ve které se sociální původ „zhodnocuje“ pouze v rámci "meritokratického" kauzálního řetězu. Jinými slovy, pokud má být prokázána "meritokratická teze“, musí platit, že vazba mezi sociálním původem a dosaženým vzděláním je výhradně nepřímou vazbou, tj. je zprostředkována mentálními schopnostmi (měřenou inteligencî) 
a případně některými dalšími faktory, které jsou kompatibilní s univerzalismem a meritokratickým principem sociální selekce (výkon).

$\mathrm{V}$ poněkud zjednodušené formě je meritokratická teze formulována na samotném počátku diskuse k základnímu modelu zhruba takto: Pokud děti pocházející z rodin s vyšším statusem jsou prokazatelně vybaveny vyššími stupni mentálních schopností než děti pocházející z rodin s nižším statusem a škola prokazatelně provádí selekci výhradně na základě schopností a výkonu (závislého v prvé řadě na schopnostech a motivaci), lze stratifikační systém reprezentovaný v základním modelu skutečně označit za meritokratický.

$Z$ toho je zřejmé, proč další kroky v rozvíjení modelu sociální stratifikace směřovaly $\mathrm{k}$ testování meritokratické teze a proč se do centra pozornosti dostává otázka distribuce vzdělání. ${ }^{6}$ Již v roce 1967 zahajuje Duncan se svými žáky nový výzkumný projekt nazvaný "Socioeconomic Background and Occupational Achievement: Extensions of a Basic Model", jehož první produkt, publikovaný již v roce 1968 [Duncan 1968], dává jasně tušit, kterým směrem se bude základní model rozvíjet. Duncan si v návaznosti na práce zabývající se úlohou schopností a inteligence v sociální mobilitě [Anderson, Brown a Bowman 1952; Young, Gibson 1963; Burt 1961] klade otázku, jakou roli hraje inteligence v mezigenerační transmisi zaměstnaneckého statusu. Podle Duncana hraje inteligence ve stratifikačním procesu dvojí roli: podílí se na mezigenerační transmisi statusu a současně roli mezigenerační transmise statusu oslabuje. Na první pohled by se mohlo zdát, že se jedná o kontradiktorní předpoklad, umožňující výzkumníkovi prokázat platnost svých hypotéz bez ohledu na závěry, ke kterým dospěje. Tak tomu ovšem není. Tento zdánlivě kontradiktorní předpoklad, vtělen do analytického modelu (diagram 2), umožnil Duncanovi nahlédnout do vzájemných vztahů mezi sociálním pưvodem, měřenou inteligencí, dosaženým vzděláním, sociálním statusem a přijmem.

Diagram 2 reprodukuje Duncanův tzv. rozširrený model. Hypotéza, kterou jeho autor do tohoto modelu vložil, je zřetelná, aniž bychom museli specifikaci modelu obšírně diskutovat. Rozdíl mezi základním modelem a tímto jeho prvním rozšířením spočívá v prvé řadě v začlenění „rané“ inteligence (INT1) a počtu sourozenců (SIB) jako dvou exogenních proměnných (nezávisle proměnných), a „pozdější" inteligence (INT) a př́jmu (INC) jako dvou endogenních proměnných (závisle proměnných). ${ }^{7}$

\footnotetext{
${ }^{6}$ Byla zde pochopitelně celá řada dalších vlivů, a to jak politických, tak vědeckých. Pokud jde o politické vlivy na uvedenou orientaci, je třeba připomenout, že konec šedesátých let přináší zjevný neúspěch liberálně demokratické koalice v USA. Fakt, že speciální vládní programy určené pro zmírnění nerovností a pro zvýšení vzestupné vzdělanostní mobility v podstatě selhávají, je argumentem pro konzervativní psychology ve prospěch teze o významnosti dědičnosti a genů pro životní úspěch. Pokud jde o vědecké impulsy, kromě sociologických prací zabývajících se otázkou třídních subkultur a socializací, o nichž bude řeč později, není možné opomenout rozsáhlou Colemanovu zprávu o nerovnostech ve vzdělanostních šancích [Coleman 1966]. ${ }^{7}$ Vycházím zde z terminologie zavedené ve strukturním modelování. Blíže k tomuto problému viz [Matějů 1989].
} 


\section{Diagram 2. Rozšîřený model - Duncan 1968}

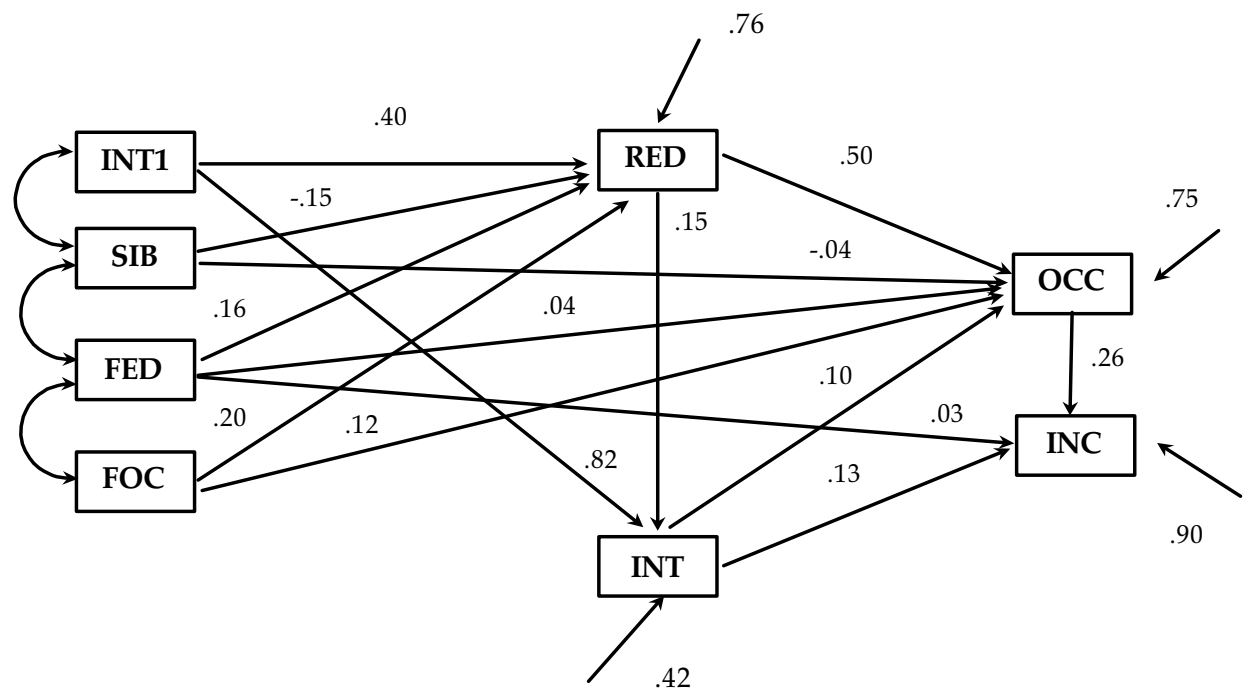

INT1 = raná inteligence

$\mathrm{SIB}=$ počet sourozenců

FED = vzdělání otce

FOC = povolání otce
RED = dosažené vzdělání

INT = později měřená inteligence

OCC $=$ povolání $\mathrm{v}$ době šetření

INC $=$ př́ijem $\mathrm{v}$ době šetření

Rozbor modelu a odhadnutých parametrů vedl Duncana na první pohled k nejednoznačnému závěru. Ukázalo se totiž, že "zahrnutí měřené inteligence do stratifikačního modelu předchozí diagnózu (založenou na základním modelu - pozn. autora) komplikuje i vyjasňuje" [Duncan 1968: 8]. Podíváme-li se však spolu s autorem na výsledky, snadno jeho postoj pochopíme. Model jako celek vyčerpává 42 \% variance dosaženého vzdělání. ${ }^{8} \mathrm{Z}$ toho 16 \% připadá na přímý vliv inteligence a dalších 14 \% připadá na vliv sociálního původu realizujícího se prostřednictvím inteligence. Pouze 11 \% variance připadá na př́mý vliv sociálního původu. Závěr, ke kterému Duncan dochází, je tedy nakonec poměrně optimistický: inteligence sama o sobě vyčerpává více variance vzdělání než kombinace tří proměnných vyjadřujících sociální původ - pokud nebereme v úvahu jejich vliv realizující se prostřednictvím inteligence. Pokud jde o roli inteligence ve zprostředkování mezi sociálním původem a dosaženým vzděláním, ukazuje se, že značná část vlivu sociálního původu se realizuje díky korelaci mezi sociálním původem a inteligencí, aniž bychom nyní roze-

\footnotetext{
${ }^{8} \mathrm{~K}$ tomuto údaji dospějeme tak, že parametr vyjadřující residuální efekty působící na danou proměnnou (0.76) převedeme na residuální variance $\left(0.76^{2}=0.58\right)$. Doplněk do 1 (či do $100 \%$ ) pak představuje míru "determinace“ této proměnné daným modelem. V našem případě tedy 42 \% variance proměnné RED lze vysvětlit proměnnými zahrnutými do modelu.
} 


\section{Diagram 3. Možná modifikace Duncanova rozšîreného modelu [Matějů 1990]}

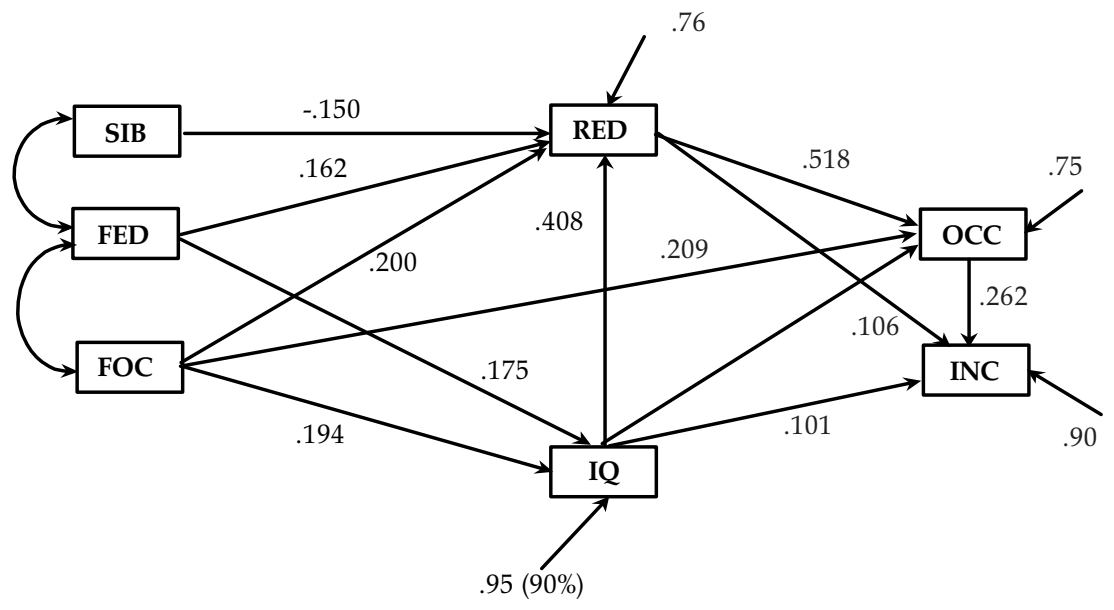

INT = měřená inteligence
FED = vzdělání otce
FOC = povolání otce
SIB = počet sourozenců

RED = dosažené vzdělání

OCC $=$ povolání $\mathrm{v}$ době šetření

INC $=$ přijem $v$ době šetření

bírali, zda se jedná o korelaci způsobenou dědičností nebo vlivem prostředí, či kombinací obou těchto faktorů.

Duncan z těchto výsledků usuzuje, že americký ideál rovnosti přiležitostí se uskutečňuje, že postup školským systémem je podmíněn schopnostmi jedince přinejmenším stejně jako tím, z jaké rodiny pochází. Fakt, že byl identifikován vliv sociálního původu nezávisle na inteligenci, podle Duncana ukazuje, že Spojené státy sice nedosáhly ideálu „čisté meritokracie“, nicméně, jak naznačují ostatní výsledky modelu, nejsou od toho ideálu př́liš daleko.

Pozdější vývoj strukturního modelování poskytuje nové možnosti zjednodušení rozšíreného Duncanova modelu a jeho modifikace. Modifikace modelu, jejíž výsledek je zobrazen v diagramu 3, si kladla pouze didaktické cíle, tj. zpřehlednit vztah mezi sociálním původem, inteligencí a vzděláním. Z modelu byly na základě testu významnosti vyloučeny nepodstatné vazby a místo dvou proměnných vyjadřujících inteligenci byla použita pouze jedna („pozdní inteligence). Z výsledků modifikovaného modelu je žrejmé, že variance v inteligenci je pouze z $10 \%$ určena sociálním původem tak, jak je reprezentován v původním Duncanově modelu (tj. vzděláním a zaměstnaneckým statusem otce). Přitom inteligence je evidentně nejsilnějším zdrojem vysvětlené variance dosaženého vzdělání (0.408). Celkové efekty sociálního původu (FED: 0.231, FOC: 0.276) rovněž nejsou zanedbatelné, ale pouze zhruba 30 \% těchto 
efektů se realizuje prostřednictvím inteligence, tzn., že jejich přímé efekty jsou nižší (FED: 0.162, FOC: 0.200).

$\mathrm{V}$ této souvislosti je instruktivní Duncanova polemika se Sextonovou [Sexton 1961], která ve své práci tvrdila, že „Vzhledem k těsnému vztahu mezi IQ a sociálním původem se zdá, že používání IQ testů slouží destruktivně, nebot' slouží jako cement fixující studenty $\mathrm{k}$ sociální třídě výchozí rodiny. IQ je tedy skvělým prostředkem ospravedlnění třídních nerovností" [Sexton 1961: 51]. Duncan na základě svých výsledků ironicky poznamenává: „Závěr Sextonové je polopravda, ne-li ještě méně než polopravda. Je to podivný cement, který dovoluje, aby značný podíl variance $\mathrm{v}$ dosažené pozici nebyl svázán se sociální třídou výchozí rodiny“ [Duncan 1968: 10].

Pokud jde o Duncana a jeho spolupracovníky, lze říci, že extenzi základního modelu viděli $\mathrm{v}$ prvé řadě $\mathrm{v}$ prověřování úlohy mentálních schopností (inteligence) a v experimentování s pozicí této proměnné v kauzálních modelech vysvětlujících dosažené vzdělání, případně dosažený zaměstnanecký status. I další práce [Duncan, Featherman, Duncan 1968; Duncan, Featherman, Duncan 1972] pokračovaly tímto směrem, avšak v zásadě jen precizovaly závěry obsažené v "Ability and Achievement“. Diagram 4, převzatý z jedné z těchto studií [Duncan, Featherman, Duncan 1972], je toho dokladem.

\section{Vývoj sociálně psychologického modelu}

Ve stejné době, kdy Duncan a Featherman precizují svůj rozšířený model [Duncan, Haller, Portes 1968; Duncan, Featherman 1972], Robert M. Hauser, rovněž Duncanův žák, pracuje na projektu, jehož cílem je objasnit vztahy mezi sociálně ekonomickým původem, charakteristikami školy a školním úspěchem [Hauser 1971]. Jako asistent $W$. Sewella je současně členem týmu, který do stratifikačního výzkumu a do extenze základního Duncanova modelu vnese další důležitý prvek, tj. sociálně psychologické faktory. Nebyla to tedy pouze shoda okolností, že o několik let později právě Sewell a Hauser měli největší zásluhu na rozvoji tzv. "sociálně psychologického modelu sociální stratifikace".

Zatímco Hauser se ve své disertaci [Hauser 1971] koncentruje na roli školy a usiluje o nalezení osobnostních a zejména kontextuálních determinant školního úspěchu jako jednoho z kořenů, z nichž později vyrůstá profesní kariéra a zaměstnanecký status, William Sewell pokračuje ve svém studiu socializace [Sewell 1961, 1963] a orientuje se na úlohu aspirací, a tudíž na roli rodiny a toho, co nazývá "významným sociálním okolím“ („significant others“). Teoretické základy sociálně psychologického modelu sociální stratifikace, který později dostane pracovní název Wisconsinský model, klade dvojice autorů Sewell a Shah již v roce 1967 [Sewell a Shah 1967], tedy ve stejnou dobu, kdy je publikován Blau-Duncanův základní model. Sewell a Shah v této své práci předkládají první verzi sociálně psychologického výkladu stratifikačního procesu. Ačkoli základy sociálně psychologického přístupu k sociální stratifikaci byly položeny již v řadě dřívějších prací [Parsons 1959; Sewell 


\section{Diagram 4. Model Duncan - Featherman - Duncan 1969}

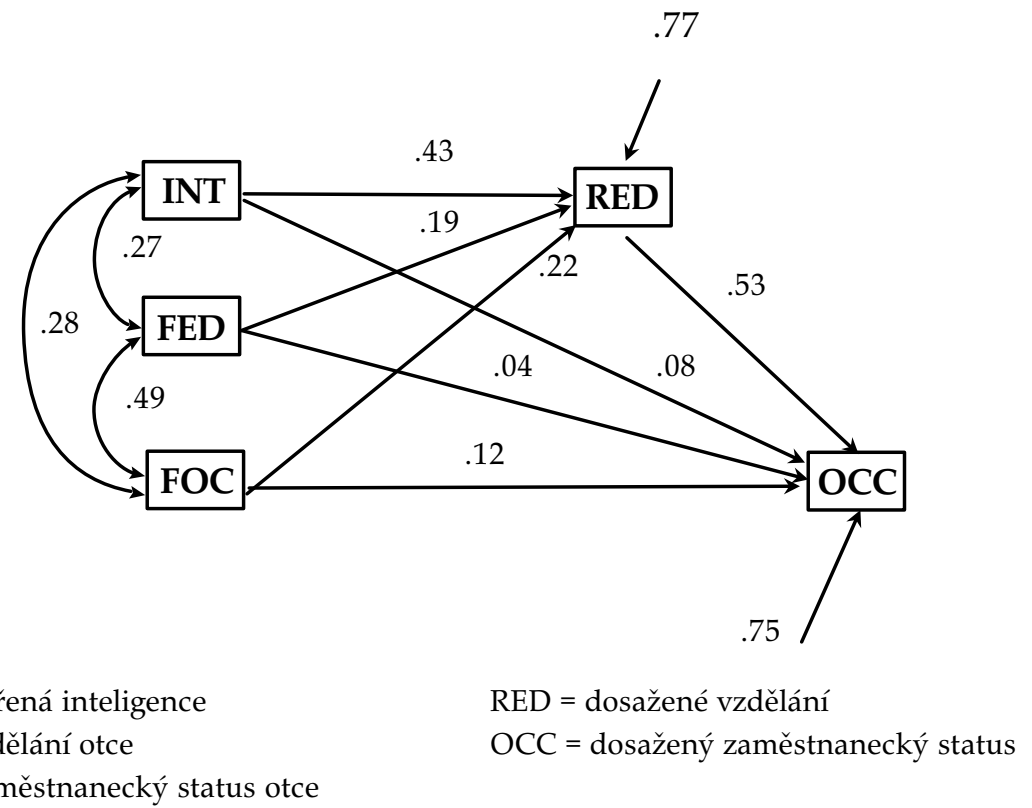

1961; Kohn 1959; Rosen, D’Andrade 1959; Brim 1960 aj.], jejich systematická analýza v rámci výzkumu sociální stratifikace se prakticky odvíjí od této práce. Jsou zde poprvé formulovány hypotézy, které se později stanou předmětem testování na datech pocházejících z longitudinálního výzkumu žáků ve státě Wisconsin a data z toho výzkumu jsou zde rovněž poprvé použita pro ilustraci problému.

Sewell a Shah vycházejí ze závěrů, ke kterým do té doby dospěl stratifikační výzkum, zejména pak ze zjištění, že v procesu alokace jedinců na pozice $\mathrm{v}$ zaměstnaneckém systému hraje klíčovou roli vzdělání, jehož prostřednictvím se realizuje převážná většina efektu sociálního původu. Akceptují rovněž závěry, podle kterých úloha školy spočívá $\mathrm{v}$ tom, že třídí jedince podle rozdílů ve schopnostech a provádí jejich distribuci do vzdělávacích "koleji“ či drah, které rozvíjejí jejich schopnosti a talenty. V tomto smyslu tedy Sewell a Shah akceptují to, co bylo zjištěno jejich předchůdci. Tvrdí ale, že tím se diferenciace vzdělanostních drah ještě nevysvětluje. Vedle schopností existují ještě další důležité faktory, které ovlivňují vzdělanostní dráhy. Jsou to jednak rozdíly v kvalitě předchozího vzdělání a nestejná dostupnost kvalitního vzdělání pro různé sociální skupiny, ${ }^{9}$ rozdíly v motivacích, hodnotách

\footnotetext{
${ }_{9}$ Nesmíme zapomenout, že Sewell se dlouho zabýval životními šancemi dětí pocházejících ze zemědělských oblastí a $\mathrm{z}$ farmářských rodin. V této souvislosti je pak zřejmé, co má na mysli, když hovoří o dostupnosti kvalitního vzdělání, atd.
} 
$\mathrm{a}$ aspiracích a $\mathrm{v}$ neposlední řadě rozdíly $\mathrm{v}$ ochotě rodičů a významného sociálního okolí poskytnout nejen finanční, ale zejména psychickou podporu nezbytnou k maximálnímu rozvinutí talentových dispozic a formování aspirací a životních plánů.

Samotná analýza, o kterou Sewell a Shah opírali své argumenty, byla velmi jednoduchá. Postupovali tak, že mezi sociální původ a inteligenci na jedné straně a dosažené vzdělání na straně druhé položili proměnnou vyjadřující intenzitu vzdělanostních aspirací. Je více než zřejmé, že museli dojít $\mathrm{k}$ závěru, že tyto aspirace na sebe berou úlohu významného mediátoru vlivu sociálního původu. Tím prakticky jen ilustrovali platnost výchozí teze, podle které sociální původ a mentální schopnosti jsou v podstatě jen určitým potenciálem vzdělanostní i profesní dráhy, potenciálem, který se aktivuje prostřednictvím aspirací a životních plánů. Jde tedy v prvé řadě o to, identifikovat skutečnou roli aspirací a životních plánů, dále pak jejich sociální podmíněnost a zdroje (rodinné klima, sociální okolí, vrstevníci, škola atd.). Ve svých bezprostředně následujících statích Sewell a Shah [1968a, 1968b] využivají dat z Wisconsinského panelu k analýze jednotlivých faktorů ovlivňujících formování vzdělanostních aspirací adolescentů. Jde jim především o to, demonstrovat sociální rozdíly v tom, jaké vzdělanostní dráhy dětí očekávají jejich rodiče, sociální diferenciaci hodnot spojovaných se vzděláním, ukázat, jak se v tomto směru projevuje diskrepance mezi otcem a matkou v úrovni dosaženého vzdělání atd. Základní tezi, která je $\mathrm{v}$ těchto studiích $\mathrm{z}$ různých stran podporována, je možné vyjádřit asi takto: Po kontrole důležitých individuálních i kontextuálních charakteristik zůstává značná část rozdílů mezi sociálními třídami v aspiracích, a tudíž i v dosaženém vzdělání nevysvětlena. Proto, aniž by se popíral význam sociálních tříd, musí modely usilující o vysvětlení vzdělanostních nerovností zahrnout specifické proměnné vyjadřující vlivy rodinného prostředí a hodnotové orientace či aspirace.

Ačkoli modely, o něž se výše uvedení autoři opírali, byly velmi jednoduché a v podstatě ilustrativní, postupně připravovaly půdu pro specifikaci tzv. sociálně psychologického modelu sociální stratifikace, jehož vývoj začal v roce 1969 a trval až do roku 1983, kdy byla publikována jeho zatím finální verze [Hauser, Tsai, Sewell 1983].

První formulace tzv. sociálně psychologického modelu se objevuje v roce 1969 v práci autorů Sewella, Hallera a Portese [1969]. Autoři zde formulují to, co sami nazývají "logicky konzistentní sociálně psychologický model“. Tento model je založen na argumentu, že mezi stratifikační a intelektuální "vstupy“ na jedné straně (tj. sociální původ a mentální schopnosti) a stratifikační "výstupy“ (dosažené vzdělání, zaměstnanecký status) na straně druhé je třeba vložit sadu proměnných vyjadřujících sociálně psychologické a behaviorální mechanismy. Konkrétně se model opírá o následující hypotézy:

a) určité sociálně strukturní a psychologické faktory (sociální původ, mentální schopnosti atd.) ovlivňují jak charakter působení "sociálně významného okolí“ na adolescenta, tak ohodnocení svých vlastních schopností;

b) působení významného sociálního okolí a zřejmě i odhad vlastních schopností ovlivňují úroveň vzdělanostních a profesních aspirací; 
Diagram 5. Sociálně psychologický model: Sewell - Haller - Portes 1969

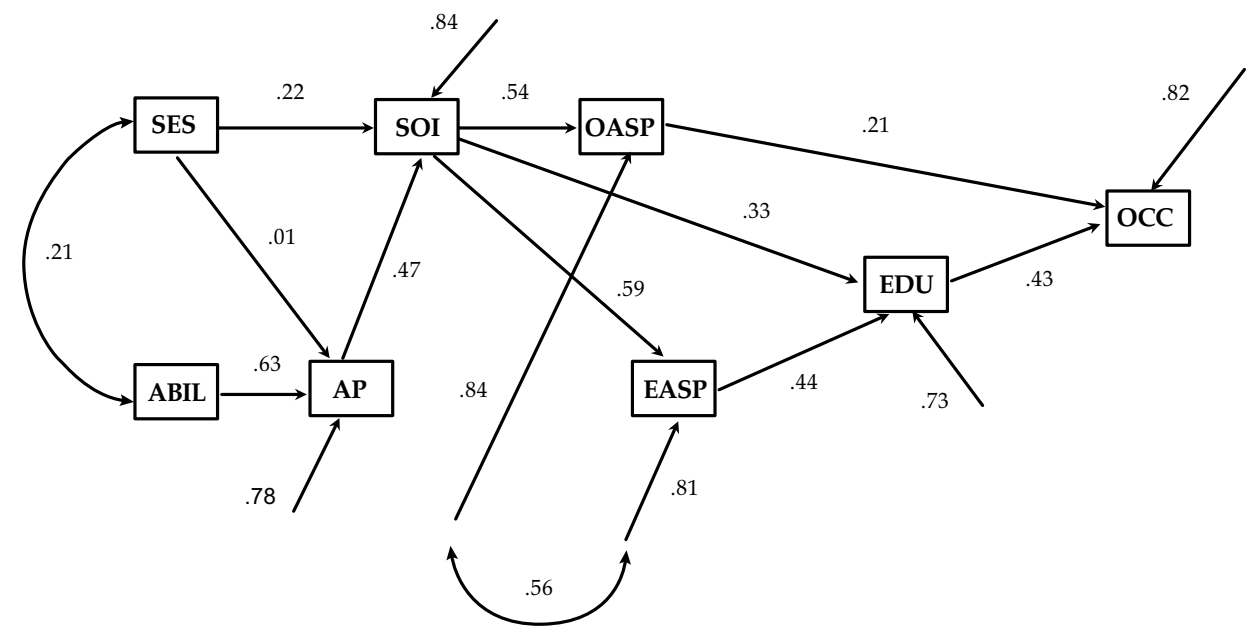

SES = sociálně ekonomický původ

OASP $=$ profesní aspirace

$\mathrm{ABIL}=$ mentální schopnosti (IQ)

EASP $=$ vzdělanostní aspirace

$\mathrm{AP}=$ školní výsledky (známky)

EDU = dosažené vzdělání

SOI = významné sociální okolí

OCC $=$ dosažený zaměstnanecký status

c) úroveň aspirací má zásadní vliv na dosažené vzdělání;

d) vzdělání zásadním způsobem ovlivňuje dosažený zaměstnanecký status.

Model, který podle těchto výchozích hypotéz Sewell, Haller a Portes specifikovali, je uveden v diagramu 5. Při specifikaci tohoto modelu byly, tak jako ve většině př́ípadů, brány v úvahu nejen vstupní teoretické předpoklady a hypotézy, ale rovněž omezení plynoucí z disponibilních dat. ${ }^{10}$

V souladu s autory lze model "číst“ následujícím způsobem:

a) Již dřívější výzkumy a modely prokázaly pozitivní korelaci mezi sociálně ekonomickým pưvodem (SES) a mentálními schopnostmi (ABIL).

b) Mentální schopnosti (ABIL) výrazně determinují školní výkon (AP).

\footnotetext{
${ }^{10} \mathrm{~V}$ této stati není místo na další detaily, ale je třeba připomenout, že tzv. Wisconsinský panel, na jehož datech stál celý vývoj Wisconsinského modelu, nebyl založen jako panel pro stratifikační výzkum, ale jako v podstatě statistické šetření pro čistě administrativní účely (šetření bylo provedeno v roce 1957 na všech žácích posledních ročníků tzv. "high school“ ve státě Wisconsin). Teprve po té, co Sewell získává data z tohoto šetření pro vlastní výzkumný projekt, dostává tento výchozí datový soubor charakter panelu, který je znovu „otevřen“ v roce 1964 a je dále sledován až do současnosti.
} 
c) Klíčovou proměnnou modelu je vliv „významného sociálního okoli“ (SOI). ${ }^{11}$ Experimentální psychologický výzkum [Sherif 1935; Herriot 1963] již prokázal důležitost sociálního okolí v procesu formování vlastních aspirací. Tento model staví rovněž hypotézu, podle které působení významného sociálního okolí (SOI) je výrazně ovlivňováno mentálními schopnostmi (ABIL).

d) Předchozí hypotéza se opírá o předpoklad, že ti, se kterými je adolescent v kontaktu, zakládají svá očekávání a povzbuzování zpravidla na prokázaných schopnostech adolescenta. To ovšem současně znamená, že efekt mentálních schopností na SOI je nepřímý, tj. realizuje se prostřednictvím školního výkonu, resp. školního úspěchu (AP). Od adolescenta se tedy očekává tím více, čím větší naději na jeho úspěch dávají aktuálně prokázané schopnosti, a to bez ohledu na sociálně ekonomický původ.

e) Bez ohledu na výše uvedenou hypotézu nelze vyloučit, že existuje i přímý efekt sociálně ekonomického původu na působení významného sociálního okolí. Toto přímé působení je konzistentní s tezí o tendenci k mezigenerační kontinuitě sociálně ekonomického statusu.

f) Vliv sociálně ekonomického původu na školní úspěch (tzn. předpoklad, že učitelé při „známkování“ zohledňují sociální původ) je, jak poznamenávají autoři modelu, sice nezřídka diskutován, ale nebyl zatím dostatečně prokázán. Model tuto vazbu ovšem připouští (SES => AP).

g) Vliv očekávání a podpory ze strany významného sociálního okolí (SOI) na karié$\mathrm{ru}$ adolescenta se realizuje $\mathrm{v}$ prvé řadě prostřednictvím formování jeho vzdělanostních a profesních aspirací (EASP, OASP).

h) Dosažené vzdělání je v prvé řadě určeno vzdělanostními aspiracemi a očekáváními ze strany významného sociálního okolí. Přímý efekt sociálního původu a mentálních schopností na dosažené vzdělání se neočekává.

i) Dosažený zaměstnanecký status je přímo ovlivněn pouze dosaženým vzděláním a profesními aspiracemi. Přímý vliv sociálního pưvodu se opět nepředpokládá.

Jednoduše řečeno, tento model postavil mezi sociální původ na jedné straně a dosažené vzdělání a zaměstnanecký status na straně druhé řadu zprostředkujících sociálně psychologických a behaviorálních faktorů (očekávání, aspirace, výkon), které nakonec přímý vliv sociálního původu plně absorbují.

Takto specifikovaný model byl podroben testování. Zde je třeba uvést, že $\mathrm{v}$ tomto bodě bylo do modelu vneseno další podstatné omezení, nebot' jeho parametry byly odhadovány na podsouboru chlapců pocházejících z rodin farmářù.

Pokud jde o výsledky, parametry modelu potvrdily všechny hlavní hypotézy, které stály u jeho zrodu. Dủležité bylo především to, že žádná z vazeb, které v mo-

\footnotetext{
${ }^{11}$ Proměnná SOI byla definována jako index složený ze tří znaků: a) odpověd’ na otázku, zda respondent (adolescent) pocitóval ze strany rodičů povzbuzování, pokud šlo o jeho či její plán studovat na vysoké škole; b) odpověd' na otázku, zda respondent (adolescent) pocitoval ze strany učitelů povzbuzování, pokud šlo o jeho či její plán studovat na vysoké škole; c) plány nejbližších přátel studovat na vysoké škole.
} 
delu nebyly považovány za relevantní a zdůvodnitelné v kontextu navrhované teorie, se neukázala být významnou. To platí zejména o efektech sociálně ekonomického původu (SES).

To, že model byl testován na velmi specifické populaci, bylo zásadní překážkou jeho zobecnění. Proto se pouze s ročním odstupem objevuje nová verze modelu. Autoři Sewell, Haller a Ohlendorf [1970] model modifikují (viz diagram 6) a částečně i revidují hlavní závěry. Základní změna spočívá v tom, že odhad parametrů modelu na celé populaci ( $\mathrm{tj}$. na populaci s normální variancí v proměnné vyjadřující sociálně ekonomický původ) vedl k mírnému oslabení role významného sociálního okolí. Revidovaný model navíc připouští přímý vliv schopností na SOI a objevují se v něm i přímé efekty školního úspěchu na vzdělanostní aspirace a dosažené vzdělání (tyto efekty byly v první verzi modelu považovány za zprostředkované přes SOI).

Revize modelu však nezměnila hlavní závěr. Autorský tým v mírně pozměněné sestavě opět dochází k závěru, že model poskytuje kauzální argument ve prospěch hypotézy, že sociální původ a mentální schopnosti působí na vzdělanostní a zaměstnaneckou kariéru prostrednictvím intervenujících mechanismů sociálně psychologické povahy. Tzv. sociálně psychologický model sociální stratifikace tak dostává obecnější dikci i věrohodnější empirickou argumentaci.

Pro další etapu vývoje modelů stratifikačního procesu je příznačné, že na čas ustupují do pozadí teoretické otázky a řeší se problémy spíše metodologické. Po zveřejnění modelu vyvinutého autorskou trojicí Sewell, Haller a Ohlendorf se vývoj modelů stratifikačního procesu ubírá dvěma směry. Jednak jsou specifikovány a testovány modely založené na sledování životních drah sourozenců. Paralelně s tím jsou metodologicky ověřovány hlavní závěry, k nimž dospěli Sewell, Haller a Ohlendorf. Jejich model byl sice považován za teoreticky velmi konzistentní, avšak po stránce metodologické byly formulovány vážné výhrady.

Modely opírající se o data o sourozencích vycházely z předpokladu, že efekt rodiny a sociálního pưvodu lze spolehlivěji identifikovat jako tu část variance, která je „osudu“ sourozenců společná (to znamená po kontrole jejich individuálních charakteristik). Tato větev vývoje modelů sociální stratifikace by ovšem vyžadovala samostatný rozbor, a to především proto, že ačkoli v mnoha směrech výzkum ubírající se tímto směrem přispěl k vyjasnění řady otázek kladených těmi, kteří se podíleli na rozvoji sociálně psychologického modelu sociální stratifikace, přinesl i řadu argumentů dávající za pravdu těm, kteří byli v opozici vůči sociálně psychologické interpretaci reprodukce nerovností [např. Olneck, Crouse 1979; Olneck, Bills 1980, Jencks et al. 1972, 1979 atd.].

\section{Vývoj tzv. „Wisconsinského modelu“}

Pokud jde o další vývoj sociálně psychologického modelu sociální stratifikace, bylo již řečeno, že vlády se ujímá metodologicky zdatná generace žáků O. D. Duncana. Již v roce 1972 vychází Hauserova stat' „Disaggregating a Social-Psychological Model of Educational Attainment“" [Hauser 1972], která možná do značné míry odradila vy- 
sloveně teoreticky orientované stoupence sociálně psychologického modelu, ale zřetelně ukázala, kudy se vývoj v zájmu verifikace modelu bude dále ubírat.

Hauser otevřel a začal řešit jeden $\mathrm{z}$ hlavních problémů výchozího modelu, tj. fakt, že dvě klíčové proměnné modelu, tj. sociálně ekonomický původ (SES) a vliv významného sociálního okolí (SOI), byly pro analýzu definovány jako lineární indexy. Tím se přirozeně ztratila informace o jejich vnitřní struktuře, která může být variantní podle toho, jak je specifikován zbytek strukturního modelu. Metodologicky závažnější argument však spočíval v tom, že použití indexů, bez ohledu na to, zda váhy jednotlivých proměnných jsou určeny arbitrárně nebo na základě předchozí aplikace faktorové analýzy, neumožňuje mít pod kontrolou chybu měření v původních indikátorech. Hauser využil svých předchozích zkušeností z vývoje tzv. MIMIC modelu [Hauser a Goldberger 1971] a provedl revizi původního modelu. Tato revize spočívala v tom, že oba latentní konstrukty byly definovány "uvnitř̆“ kauzálního modelu. Sociálně ekonomický původ (SES) byl v modelu definován jako lineární kompozit čtyř př́mo měřených proměnných (vzdělání otce, vzdělání matky, zaměstnanecký status otce a př́jmy obou rodičů). Podobným způsobem byl definován konstrukt vyjadřující vliv sociálně významného okolí (SOI), tj. jako lineární produkt tří proměnných (povzbuzování ze strany rodičù, povzbuzování ze strany učitelů, plány vrstevníků). Specifikaci revidovaného modelu zde z úsporných důvodů neuvádíme v grafické podobě. Princip definice latentních proměnných konstrukcí tzv. MIMIC modelu (multiple indicators - multiple causes) by však měl být zřjejmý z diagramu 8, kde reprodukujeme tu část pozdějšího tzv. Wisconsinského modelu, kde je definována latentní proměnná SOI.

Odhad parametrů revidovaného modelu nedopadl přiliš ve prospěch Sewella a jeho spolupracovníků. Hauser však volí velmi opatrné formulace a tvrdí, že parametry revidovaného modelu sice příliš nepodporují hypotézu vtělenou do pưvodního modelu, ale že není vyloučeno, že jeho specifikace nemusí být správná. Dochází totiž k závěru, že efekty, které Sewell z modelu vynechává, nelze pro jejich signifikanci vynechat (zejména SES na EDUC), a naopak, že efekty, které v modelu byly obsaženy, se jeví být slabší než v původním modelu. Později se ukázalo, že opatrnost Hauserových formulací byla na místě. O několik let později, když byla k dispozici data z další vlny šetření, se potvrdilo jeho podezření, že model se může ještě dosti výrazně změnit tím, že budou identifikovány chyby měření hlavních proměnných.

Revize modelu však neměla pouze metodologický význam. Hauser dospěl aplikací MIMIC modelů i $\mathrm{k}$ některým věcně zajímavým závěrům, které vyplynuly $\mathrm{z}$ analýzy vnitřní struktury MIMIC modelů. Pokud jde o vnitřní strukturu sociálně ekonomického původu, model ukázal, že všechny uvedené komponenty mají zhruba stejný význam. Hauser tedy explicitně zpochybňuje platnost hypotéz, podle kterých ve stratifikačním procesu a mezigeneračním transferu nerovností dominuje některá $\mathrm{z}$ dimenzí sociálního původu, at' se jedná o příjem [Schiller 1970], vzdělání matky [Ellis a Lane 1963, Krauss 1964] nebo některé třídní aspekty povolání [Bowles 1972].

Pokud jde o latentní proměnnou „vliv významného sociálního okoli“", kterou Hauser přejmenovává na "percepce očekávání od druhých“ („perceived others' expectations“), revize modelu potvrdila hypotézu vtělenou do původního modelu, 
Diagram 6. Sociálně psychologický model: Sewell - Haller - Ohlendorf 1970

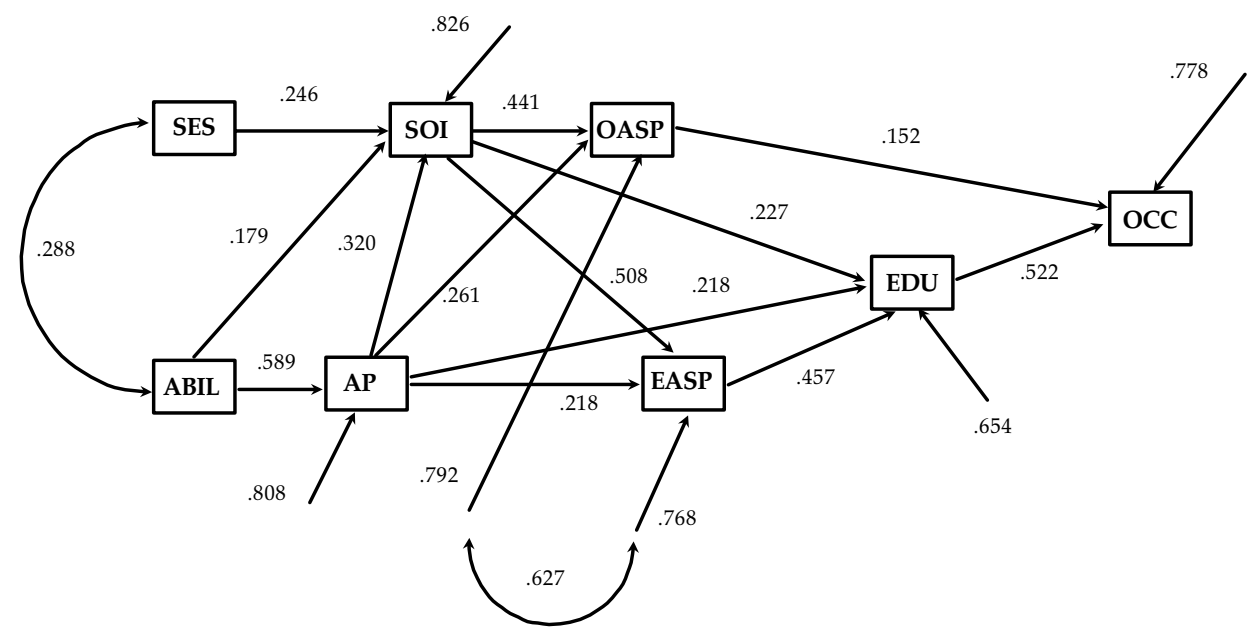

SES = sociálně ekonomický původ

OASP $=$ profesní aspirace

$\mathrm{ABIL}=$ mentální schopnosti (IQ)

EASP $=$ vzdělanostní aspirace

$\mathrm{AP}=$ školní výsledky (známky)

EDU = dosažené vzdělání

SOI = významné sociální okolí

OCC $=$ dosažený zaměstnanecký status

tj. že adolescenti integrují očekávání z různých zdrojů v jeden relativně obecný vzorec. Hauser, který se předtím věnoval úloze školy ve stratifikačním procesu, si pochopitelně všímá zejména struktury determinací a efektů těchto očekávání. Jeho zjištění jsou instruktivní:

Efekt sociálně ekonomického původu na očekávání (povzbuzovánî) ze strany rodičů a na vzdělanostní plány vrstevníků je zhruba třikrát silnější než efekt původu na povzbuzování ze strany učitelů. Povzbuzování ze strany učitelů ovšem závisí mnohem více na školním úspěchu (známkách).

Vliv mentálních schopností na všechny tři zdroje očekávání je přitom zhruba stejný, poněkud silnější vliv mentálních schopností na očekávání rodičù Hauser vysvětluje tím, že rodiče ve svých očekáváních berou v úvahu i ty aspekty mentálních schopností (respektive jejich manifestace), které se ve škole nemusí nutně projevovat.

Jako závěr pak Hauser formuluje tvrzení, že učitelé svým působením reprezentují spíše „egalitární" faktor, zatímco rodiče a vrstevníci jsou spíše „konzervativními“ faktory stratifikačního procesu, nebot' ve svém působení reflektují ve větší míře sociálně ekonomický původ. Z hlediska vývoje vzdělanostních nerovností by tedy bylo žádoucí, konstatuje autor, aby na aspirace a dosažené vzdělání adolescentů měla větší vliv jejich percepce očekávání ze strany učitelů. V realitě je tomu ovšem naopak, očekávání učitelů hrají menší význam než očekávání ze strany rodičů a studijní plány vrstevníků. 
Ve stejném roce, kdy Hauser publikuje první revizi Sewellova modelu, se objevuje druhá revize [Sewell, Hauser 1972], první z dlouhé série prací, ve kterých Hauser a Sewell postupně formují finální podobu sociálně psychologického modelu. Tato nová varianta revidovaného modelu využívá všech změn, které do modelu vnesl Hauser, navíc se v modelu objevuje jako závisle proměnná dosažený zaměstnanecký status a př́jem. Ačkoli se tato práce díky Hauserovi opírá o značně sofistikovaný metodologický a matematický aparát, Sewellův vliv je patrný v tom, že je orientovaná spíše teoreticky a věcně než metodologicky. Ačkoli se jedná o práci publikovanou mimo renomovaná sociologická periodika (vyšla v American Journal of Agricultural Economics), lze ji považovat za jednu z nejlepších, pokud jde o formulaci hlavních východisek výstavby sociálně psychologického modelu i závěrů, které do té doby z jeho testování vyplynuly.

Autoři se zde vracejí k otázce úlohy mentálních schopností ve vývoji nerovností, což je v té době opět jedno z nejkontroverznějších témat americké sociologie. Na počátku sedmdesátých let se objevují práce znovu nastolující provokativní otázku, kterou si nikoli bez smyslu pro sarkasmus v sociologii položil Young již v roce 1957 [Young 1957]. Jedná se o problém, zda mentální schopnosti jsou spíše produktem genetické dědičnosti nebo prostředí a zda meritokratický princip selekce opírající se o mentální schopnosti petrifikuje třídní rozdíly, nebo naopak vede $\mathrm{k}$ jejich zmenšování [Herrnstein 1971, 1973; Husén 1969, 1972; Jensen 1972 aj.]. Sewell a Hauser na základě výsledků analýzy svého modelu v této souvislosti formulují sociologicky relevantní závěry. Studium parametrů modelu totiž ukazuje, že celkový efekt mentálních schopností na dosažení vysokoškolského vzdělání je sice velký, ale že 84 \% tohoto efektu se realizuje prostřednictvím intervenujících proměnných sociálně psychologické povahy.

Shrnující závěr této vynikající studie je sice méně ortodoxní než závěry z prvních pokusů o formulaci sociálně psychologického modelu, avšak podpora výchozí teorii se zdá být věrohodnější. Autoři konstatují: „Z naší analýzy je zřejmé, že cesta k vyššímu zaměstnaneckému statusu vede přes vyšší vzdělání. Ukazuje se, že rodiny s vyšším statusem dokáží této cesty využít nejlépe, snad proto, že zajištují jak geny, tak stimulující prostředí, což jsou faktory, které vedou k vysokým kognitivním schopnostem, a tudíž i k lepšímu prospěchu ve škole. Dále, pozbuzování k dosažení vyššího vzdělání, jehož se dostává dětem v těchto rodinách, vede $\mathrm{k}$ jejich vyšším aspiracím, k vyššímu vzdělání, a tudíž i k vyššímu zaměstnaneckému statusu. Navíc, avšak s podstatně menší vahou, poskytují rodiny s vyšším statusem svým dětem některé další výhody, umožňující přímý mezigenerační transfer zaměstnaneckého statusu. Výsledky naší analýzy ale ukazují, že sociálně psychologické faktory, které ovlivňují dosažení vyššího vzdělání, jsou mnohem důležitější než přímé vlivy sociálně ekonomických faktorů“ [Sewell, Hauser 1972: 859].

Zdálo by se, že vývoj modelu by zde mohl být uzavřen a výchozí teorie by s jistými modifikacemi mohla být přijata. Již jsme však upozornili na to, že Hauser při formulaci závěrů ze své první revize Sewellova modelu vyjádřil pochybnost nad tím, že by se jednalo o konečné řešení, a vyslovil hypotézu, že kontrola chyb měření $\mathrm{v}$ hlavních proměnných by mohla vést $\mathrm{k}$ podstatným změnám $\mathrm{v}$ modelu. $\mathrm{V}$ roce 


\section{Diagram 7. Wisconsinský sociálně psychologický model: Sewell - Hauser} Pouze blokové schéma - bez modelů měření

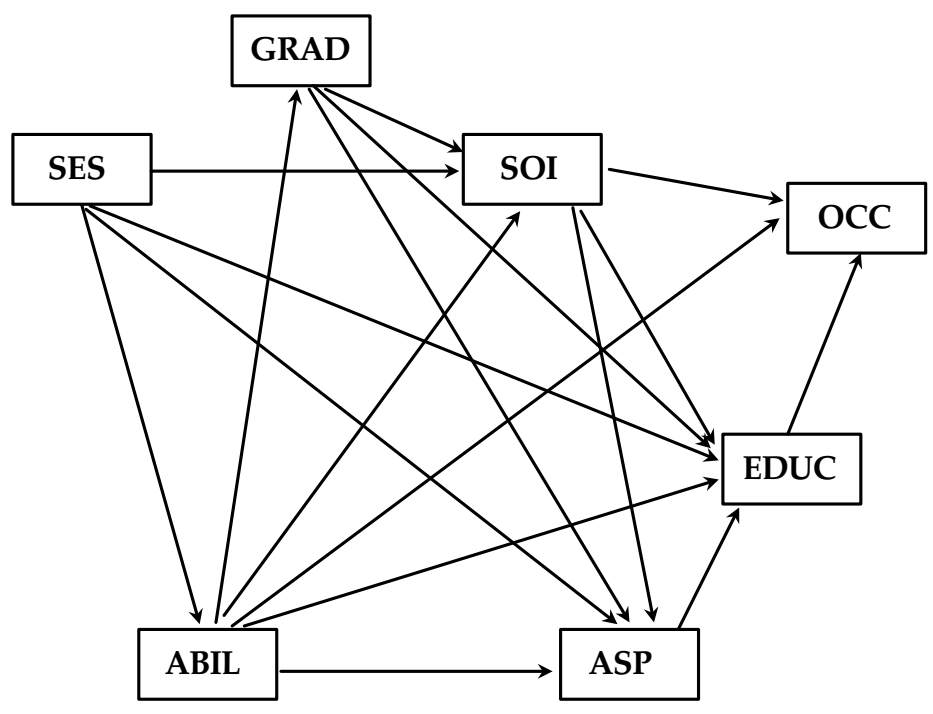

SES = sociálně ekonomický původ

$\mathrm{ABIL}=$ mentální schopnosti (IQ)

$\mathrm{AP}=$ školní výsledky (známky)

SOI = významné sociální okolí
OASP $=$ profesní aspirace

EASP = vzdělanostní aspirace

EDU = dosažené vzdělání

OCC $=$ dosažený zaměstnanecký status

1975 bylo uskutečněno další šetření na Wisconsinském panelu, které mimo jiné umožnilo na základě opakovaného zjištování klíčových údajů postavit další verzi modelu, a to verzi zahrnující již zmíněnou kontrolu v chybách měření [Hauser, Tsai, Sewell 1983]. Po metodologické stránce základní změna modelu skutečně spočívala v zavedení kontroly nad chybami měření v rozhodujících proměnných. Hauser, Tsai a Sewell však k poslední revizi modelu přistupují i s novým pohledem na úlohu strukturního modelování, které do té doby výrazně pokročilo od pouhého nástroje $\mathrm{k}$ analýze dat $\mathrm{k}$ relativně konzistentnímu teoreticko-metodologickému principu testování komplexních hypotéz. Autoři konstatují, že pưvodní Wisconsinský model byl stále rozšiřován o nové parametry na základě čistě empirických kritérií a že se vzdaloval svému základnímu poslání, tj. reprezentovat určitou komplexní teoretickou hypotézu. Kombinace těchto dvou hledisek nakonec vedla k rozhodnutí vrátit se $\mathrm{k}$ původní formulaci modelu (tj. $\mathrm{k}$ té formulaci, kterou nabídli Sewell, Haller a Ohlendorf) a testovat ji na modelu, který by ovšem plně do sebe integroval do té doby ověřené principy definice latentních proměnných a navíc kontrolu nad chybami měření. Testování modelu, který je ve schematické podobě znázorněn v diagramu 7 a 8, dalo nakonec plnou satisfakci původní formulaci modelu. Autoři konsta- 
Diagram 8. Wisconsinský sociálně psychologický model: Sewell - Hauser Partie modelu definující proměnnou „Vliv sociálně významného okolī”

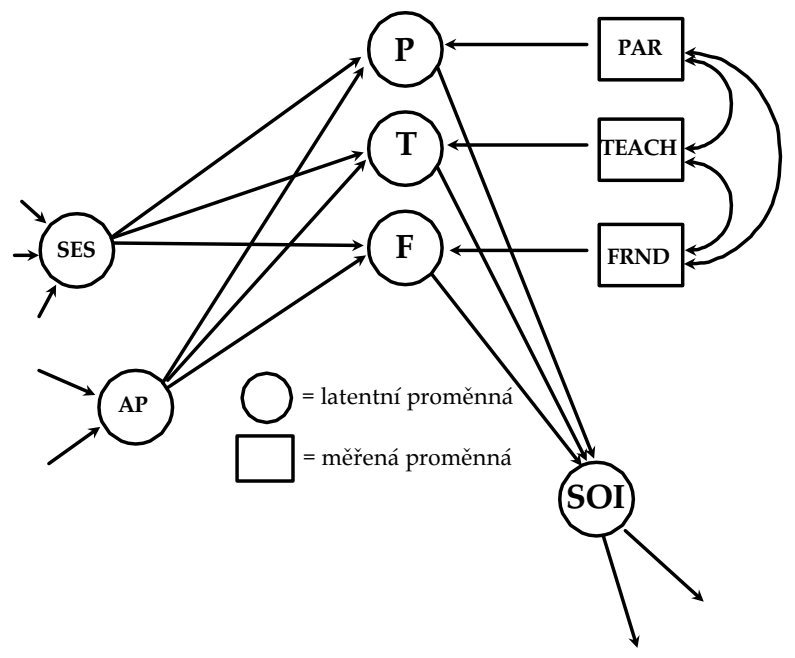

SES = sociálně ekonomický původ

$\mathrm{AP}=$ školní výkon

$\mathrm{PAR}=$ podpora rodičů $\mathrm{v}$ plánech pokračovat ve studiu

$\mathrm{TEACH}=$ podpora učitelů $\mathrm{v}$ plánech pokračovat ve studiu
FRND = vzdělanostní aspirace vrstevníků (přátel)

SOI = vliv významného sociálního okolí syntetická proměnná

tovali, že SHO model (Sewell-Haller-Portes) je oprávněnou hypotézou výkladu sociální stratifikace v USA. Autoři se vrací k Blau-Duncanově formulaci a tvrdí, že většina efektu vzdělání na zaměstnanecký status neplyne z toho, že by vzdělání hrálo roli nástroje přenosu sociálně ekonomického statusu z generace na generaci, ale z toho, že v procesu získávání vzdělání působí sociálně psychologické procesy včetně těch, které jsou reprezentovány v modelu.

\section{Kritická reflexe sociálně psychologického modelu}

Revizí modelu z roku 1983 [Hauser, Tsai, Sewell 1983] vývoj sociálně psychologického modelu sociální stratifikace zatím končí. Tato revize byla nejen návratem k původní kauzální hypotéze vtělené do modelu z roku 1970, ale rovněž reakcí na řadu pokusů model replikovat, vysvětlovat, dále rozšiřovat či podrobovat kritice. Jak uvádí Campbell [1983], Wisconsinský model patřil podle citačního indexu k nejdiskutovanějším produktům sociologie ve Spojených státech a jen první vlna článků z let 1969 až 1975 vyvolala více než 500 reakcí. Shrnutí kritiky modelu by si vyžá- 
dalo další stat'. Zde se pokusím o načrtnutí jen základních problémů, na které kritikové tohoto modelu upozornili, a to bud' explicitně [Kerckhoff 1976; Jencks, Crouse, Mueser 1983] nebo implicitně konstrukcí alternativního výkladového paradigmatu a odpovídajícího analytického modelu [např́iklad Goldthorpe 1996; Breen, Goldthorpe 1997].

Základní spor se z pochopitelných důvodů vedl a stále vede o to, zda "socializační perspektiva" výkladu mezigenerační reprodukce sociálního statusu zdưrazňující vliv charakteristik jednotlivce (měřené schopnosti, aspirace), jeho rodiny (sociální původ) a významného sociálního okolí (spolužáci, vrstevníci) na dosažené vzdělání a zaměstnanecký status, dostatečně reflektuje existenci mechanismů, které omezují samotný rozvoj aspirací, a tudíž i životních plánů. Tyto mechanismy, zdůrazňované v rámci tzv. „alokační perspektivy“, působí jako více či méně vnímané sociální (tř́ídnî) či etnické (rasové) bariéry dosažení vyššího vzdělání či postavení v zaměstnanecké struktuře. Alan Kerckhoff [1976], který jako první proti sobě postavil "socializační a "alokačni“ paradigma, zdůraznil, že přes evidentní přínos sociálně psychologického modelu pro pochopení reprodukce nerovností socializační paradigma nechává stranou pozornosti skutečnost, že lidé na různých stupních stratifikačního systému docela dobře vnímají, jaké možnosti se jim a jejich dětem reálně otevírají. Důležitou roli tedy hrají očekávání, která se přizpůsobují reálnému světu. Kerckhoff $\mathrm{s}$ odvoláním na řadu studií, které vychází z třídní perspektivy reprodukce nerovností, uvádí, že aspirace a motivace adolescentů, které představují centrální výkladový princip socializačního modelu, významným způsobem ovlivňují očekávání toho, čeho jednou budou moci dosáhnout. Proto nap̌ríklad socializační model nefunguje tak dobře pro populaci černochů jako bělochů, což Kerckhoff vysvětluje tím, že bez ohledu na výsledky socializačního procesu vnější omezení snižují šance na získání vyššího vzdělání a zaměstnaneckého statusu. Ke stejnému závěru dochází na základě zjištění, podle kterého očekávání žákủ devátých a desátých tříd amerických "high schools" predikují to, čeho později skutečně dosáhli (vzdělání, status), hưře, než jejich očekávání ve dvanáctém ročníku. To znamená, že u dětí s přibývajícím věkem slábne přesvědčení, že ve společnosti existují rovné šance v životě dosáhnout toho, čeho si člověk přeje dosáhnout. Jinými slovy, socializační model je podle většiny jeho kritiků sdílejících spíše "alokační perspektivu“ málo citlivý na diskriminaci a třídní bariéry. To však ani podle těch nejradikálnějších kritikủ nesnižuje význam socializačního modelu. Spíše to vede k opatrnosti aplikovat jej jako jediné paradigma na výklad mezigenerační reprodukce nerovností.

Metodologické kritice socializačního modelu, která by v souvislosti s vývojem strukturního modelování mohla vznést požadavky na důslednější ošetření chyb měření, a to zejména $\mathrm{v}$ konstrukci kompozitů měřících sociální status výchozí rodiny (SES), předešli autoři Wisconsinského modelu již v roce 1983, kdy revidovali nejen kauzální hypotézu, ale též model měření, do kterého v mnohem větší míre než v minulosti zahrnuli kontrolu nad chybami měření a korelace mezi nimi. To ocenili i kritici předchozích verzí modelu a konstatovali, že vliv sociálního původu (vysvětlená variance) se touto operací zvýšil. To jen dokazuje, že kritika sociálně psychologického modelu tak, jak byl vyvinut Sewellem a Hauserem, má-li být efektivní, je tře- 
ba, aby zpochybnila samotná jeho teoretická východiska. Po metodologické stránce je model pravděpodobně velmi obtížně napadnutelný.

Implicitní kritika paradigmatu, ze kterého vychází sociálně psychologický model, má současné představitele zejména ve stoupencích teorie racionálního jednání, která si klade za cíl vysvětlit přetrvávající třídní nerovnosti v šancích na dosažení vyššího vzdělání v moderních industriálních společnostech. Hlavními představiteli této teorie jsou John Goldthorpe (mimochodem dlouholetý kritik americké stratifikační školy, viz např. Matějů 1992) a Richard Breen [Goldthorpe 1996; Breen, Goldthorpe 1997]. Přístup k reprodukci nerovností v procesu dosahování vzdělání a tudíž i sociálního statusu je součástí úsilí o teoreticky dobře zakotvené vysvětlení neměnných (empiricky doložených) a přetrvávajících třídních rozdílů v životních šancích.

Protože vzdělání hraje klíčovou roli v determinaci životních šancí jednotlivců, je třeba najít ověřitelné teoretické vysvětlení pro zjevnou stabilitu šancí v dosahování vysokoškolského vzdělání. Podle Goldthorpa však může být takové vysvětlení nalezeno jen ztěží, pokud nevezmeme v úvahu mikro-sociální kořeny makro-sociálních "konstant“. Abychom porozuměli přetrvávajícím nerovnostem, musíme vzít v úvahu „pojem racionality“ (notion of rationality), předpokládající, že sociální aktéři mají své cíle a alternativní prostředky $\mathrm{k}$ jejich dosažení. Při výběru $\mathrm{z}$ těchto prostředků poměřují náklady, rizika a výnosy a nejednají pouze podle sociálních nebo kulturních norem nebo hodnot typických pro třídu, ke které náleží [Goldthorpe 1996: 485]. Fakticky se jedná o rozpracování Boudonovy teorie reprodukce vzdělanostních nerovností, která je založena na předpokladu, že školní kariéra je sledem rozhodnutí, ve kterých sociální aktér vyhodnocuje a porovnává užitek, náklady a riziko plynoucí z volby té které vzdělávací dráhy, např. $z$ volby mezi pokračováním ve studiu nebo jeho opuštěním atd. Goldthorpe akceptoval Boudonovo rozlišení mezi primárními vlivy (schopnostmi, školním výkonem) a sekundárními vlivy (faktory, které působí v té fázi, ve které se vzdělávací systém větvî). Vyvinul teoretický a analytický přístup vycházející z toho, že „pozornost musí být zaměřena spíše na sekundární než primární vlivy, pokud má být otázka změny, či spíše absence změny, v třídních rozdílech za podmínek expanze vzdělávacího systému efektivně uchopena“ [Goldthorpe 1996: 491].

Toto východisko je v souladu s dalším explicitním předpokladem, a sice, že expanze vzdělávacího systému vede ke slábnutí role primárních faktorů (selektivita založená na výkonu slábne s každou následnou tranzicî). To má za následek, že stále větší počet dětí usiluje ve svém vzdělávání o stále ambicióznější cíle. Rozdíly mezi třídami při dosahování těchto cílů přetrvávají, protože $\mathrm{u}$ nich nedošlo $\mathrm{k}$ téměř žádné změně ve zpơsobu vyhodnocování poměru mezi náklady a výnosy. Jinými slovy, ačkoli relativní zisk z dosažení vyššího vzdělání je optikou nižších tříd větší (protože je očekávána vzestupná mobilita), relativní náklady jsou také větší (prostředky vynaložené na vzdělání jsou měřeny výší rodinného př́ijmu), a větší je tudíž i riziko neúspěchu (bud' v podobě zanechání studia nebo v podobě překážek při snaze získat jako absolvent adekvátní zaměstnánî). Tento princip platí bez ohledu na to, jak zdatně si jedinec vede na poli primárních vlivů (schopností, skutečné školní výkonnosti).

Ani poměrně silná teorie racionálního jednání však sociálně psychologické paradigma a jemu odpovídající kauzální model nevyvrací. Opět jde o komplemen- 
tární, nikoliv alternativní paradigmata. Pro ty, kteří naleznou v sociálně psychologickém modelu inspiraci, to znamená, že paralelně s jeho budováním a testováním by měli prozkoumávat tř́ídně podmíněné vzorce rozhodování založené na percepci bariér, o kterých se rodiče i děti mohou domnívat, že sice mohou být překonatelné, ale rizika s tím spojená mohou být přiliš veliká.

\section{Závěrem}

Jistě lze položit otázku, jaký vztah mají úvahy o vývoji sociálně psychologického modelu k výzkumu sociální stratifikace v postkomunistické Evropě. Domnívám se, že informace o vývoji modelů, na jehož počátku stál Blau-Duncanův základní model, je pro nás instruktivní především jako varování před přilišným optimismem. Představa, že data $\mathrm{z}$ jednoho či několika šetření poskytnou v relativně krátkém čase odpovědi na tak závažnou otázku, jakou je proměna hluboce deformovaného stratifikačního procesu v bývalých komunistických zemích, způsobená jak dlouhodobým úsilím komunistického režimu stratifikačním procesem manipulovat, tak sebezáchovným úsilím jedinců důsledky této manipulace minimalizovat, je možná lákavá, ale podle mého soudu nerealistická. Domnívám se současně, že ještě jedno varování je více než zřejmé: př́iklad Wisconsinského panelu a na něm postavený longitudinální výzkum ukazuje, že sběr dat nemusí být nutně podřízen nějaké silné dominantní hypotéze či teorii, totéž ovšem rozhodně neplatí o analýze dat. Může se zdát paradoxní, že čím sofistikovanější metodu hodláme aplikovat, tím silnější hypotézu musíme mít na počátku.

$Z$ teoretického hlediska je vývoj sociálně psychologického modelu inspirativní především v tom, že ukazuje, jak závažnou roli hrajív dosahování cílů a tudíž i reprodukci nerovností sociálně psychologické faktory (aspirace, hodnoty, očekávání, schopnosti, výkon atd.). Přitom právě sociálně psychologické faktory mají temporalitu změny odlišnou od faktorù běžně nazývaných "strukturální" (politika, ekonomika, právo atd.). Např́iklad hodnoty spojované se vzděláním, resp. jejich eroze, se staly součástí percepce sociálního systému několika generací. Stejně je tomu s hodnotou pracovního úsilí či výkonu, schopností atd. Jsem přesvědčen, že nalezení odpovědi na otázky, jakou povahu má stratifikační systém v České republice a jak vypadá proces, který jej reprodukuje, se neobejde bez zahrnutí sociálně psychologických faktorů do analytických schémat a modelů.

Význam diskuse nad vývojem sociálně psychologického modelu sociální stratifikace ale rozhodně nespočívá v poskytnutí návodu, jak postupovat při analýze stratifikace v naší měnící se společnosti. Tento postup by nepochybně vedl ke zklamání na samotném počátku, nebot' pravděpodobně neplatí řada elementárních předpokladů aplikace tohoto modelu v té podobě, jak byl vyvinut pro Spojené státy. Rozbor hlavních modelů měl však za cíl ukázat, že analýza stratifikace se pravděpodobně ani u nás neobejde bez studia subtilnějších rovin sociální reality, jakkoli se naše společnost nachází ve fázi formování spiše robustnějších "třídních" dimenzí sociální diferenciace. 
PETR MATĚJŮ vede oddělení pro výzkum sociální stratifikace v Sociologickém ústavu Akademie věd ČR a současně pưsobí jako prorektor pro výzkum na Anglo-americké vysoké škole v Praze. Dlouhodobě se zabývá vývojem nerovností a sociální stratifikace a zejména úlohou vzděláni, vzdělanostnich nerovností a vzdělanostní mobility v mezigeneračním přenosu sociálniho statusu. V současné době vede projekt "Ekonomické, sociální a kulturní zdroje vzdělanostních nerovností a determinanty životního úspěchu: proní fáze longitudinálního výzkumu“, jehož hlavním cilem je na základě zahájeného longitudinálnîho projektu PISA-L identifikovat zdroje vzdělanostnich nerovností v České republice.

\section{Literatura}

Anderson, C. A., J. C. Brown, M. J. Bowman 1952. „Intelligence and later occupational mobility“. Journal of Political Economy 60: 218-239.

Blau, P. M., O. D. Duncan 1967. The American Occupational Structure. New York: Wiley.

Boguszak, M., I. Gabal, P. Matěju 1990. „Ke koncepcím vývoje sociální struktury v CSSR“. Sociologický časopis 26 (2): 168-186.

Boudon, R. 1974. Education, Opportunity and Social Inequality. New York: Willey.

Bowles, S. 1972. "Schooling and inequality from generation to generation“. Journal of Political Economy 80 (3): 219-251.

Breen, R., J. Goldthorpe 1997. „Explaining educational Differentials. Towards a Formal Rational Action Theory“. Rationality and Society 9 (3): 275-305.

Brim, O. G. 1960. „Personality Development as Role-Learning.“ Pp. 127-159 in Iscoe, I., H. Stevenson (eds.): Personality Development in Children. Austin: University of Texas Press.

Burt, C. 1961. „Intelligence and social mobility“. British Journal of Statistic Psychology 14: 3-24.

Campbell, R. T. 1983. "Status Attainment Research: End of the Beginning or Beginning of the End?" Sociology of Education 56: 47-62.

Coleman, J. S et al. 1966. Equality of Educational Opportunity. Supplemental Appendix. Washington: U. S. Governmental Printing Office.

Duncan, O. D. 1968. „Ability and Achievement". Eugenics Quarterly 15: 1-11.

Duncan, O. D., D. L. Featherman 1972. „Psychological and Cultural Factors in the Process of Occupational Achievement". Social Science Research 1: 121-145.

Duncan, O. D., A. O. Haller, A. Portes 1968. „Peer Influences on Aspirations: A Reinterpretation“. American Journal of Sociology 74: 119-137

Duncan, O. D., D. L. Featherman, B. Duncan 1968. „Socioeconomic Background and Occupational Achievement: Extensions of a Basic Model, Final Report". Washington, D. C.: U. S. Department of Health, Education, and Welfare, Office of Education, Bureau of Research.

Duncan, O. D., D. L. Featherman, B. Duncan 1972. Socioeconomic Background and Achievement. New York: Seminar Press.

Ellis, R., W. C. Lane 1963. „Structural supports for upward mobility“. American Sociological Review 28: 743-756.

Erikson, R., J. H. Goldthorpe 1992. The Constant Flux. A Study of Class Mobility in Industrial Societies. Oxford: Clarendon Press.

Glass, D. V. (ed. ) 1956. Social Mobility in Britain. Glencoe: Free Press.

Goldthorpe, J. 1996. "Class analysis and the reorientation of class theory: the case of persisting differential in educational attainment". British Journal of Sociology 47 (5): 481-505 
Hauser, R. M. 1971. Socioeconomic Background and Educational Performance. Washington, D. C.: The Arnold \& Caroline Rose Monograph Series in Sociology.

Hauser, R. M., A. S. Goldberger 1971. „The treatment of unobservable variables in path analysis“. Pp. 81-117 in Costner, H. (ed.): Sociological Methodology. San Francisco: Jossey-Bass.

Hauser, R. M., W. H. Sewell 1976. On The Effects of Families and Family Structure on Achievements. UW-Madison, CDE working paper 76-32.

Hauser, R. M., W. H. Sewell 1984. Family Effects in Simple Models of Education, Occupational Status and Earnings: Findings from the Wisconsin and Kalamazoo Studies. UW-Madison, CDE Working Paper 84-29.

Hauser, R. M., W. H. Sewell 1985. „Birth Order and Educational Attainment in Full Sibships“. American Educational Research Journal 22: 1-23.

Hauser, R. M., W. H. Sewell 1986. „Family Effects in Simple Models of Education, Occupational Status, and Earnings: Findings from the Wisconsin and Kalamazoo Studies“. Journal of Labor Economics 4: 83-115.

Hauser, R. M., S. L. Tsai, W. H. Sewell 1983. „A Model of Stratification with Response Error in Social and Psychological Variables". Sociology of Education 56: 20-46.

Hauser, R. M. 1972. „Disaggregating a Social-Psychological Model of Educational Attainment". Social Science Research 1: 159-188.

Herriot, R. E. 1963. „Some social determinants of educational aspirations“. Harvard Educational Review 33: 157-177.

Herrnstein, R. J. 1971. „IQ“. Atlantic Monthly 228 (3): 44-64.

Herrnstein, R. J. 1973. IQ in the Meritocracy. Boston and Toronto: Little, Brown \& Co.

Husén, T. 1969. Talent, Opportunity and Career: A Twenty-Six Year Follow-up of 1500 Individuals. Stockholm: Almquist \& Wiksell.

Husén, T. 1972. Social Background and Educational Career: Research Perspectives on Equality of Educational Opportunity. Paris: OECD.

Jencks, C., J. Crouse, P. Mueser 1983. „The Wisconsin Model of Status Attainment: A National Replication with Improved Measures of Ability and Aspirations“. Sociology of Education (January 1983): 3-19.

Jencks, C. et al. 1972. Inequality. A Reassessment of the Effect of Family and Schooling in America. New York: Harper Colophon Books.

Jencks, C. et al. 1979. Who Gets Ahead? The Determinants of Economic Success in America. New York: Basic Books.

Jensen, A. R. 1972. Genetics and Education. London: Methuen.

Kerckhoff, A. C. 1976. „The Status Attainment Process: Socialization or Allocation?" Social Forces 55: 368-381.

Kohn, M. L. 1959. „Social Class and Parental Values“. American Journal of Sociology 64: 337-351.

Krauss, I. 1964. "Sources of educational aspirations among working-class youth“. American Sociological Review 29: 867-879.

Lipset, S. M., R. Bendix 1959. Social Mobility in Industrial Society. „Berkeley: University of California Press.

Machonin. P. a kol. 1969. Československá společnost. Sociologická analýza sociální stratifikace. Bratislava: Epocha.

Matějů, P. 1989. „Metoda strukturního modelování. Přehled základních problémů“. Sociologický časopis 25 (4): 399-418.

Matějů, P. 1990. Stratification System and Economy in the Period of Transition. Economic aspects of "de-stratification" in former socialist countries - the case of Czechoslovakia. Referát prezentovaný a distribuovaný na semináři „Central and Eastern Europe in Transition: Economic Sociology in Comparative Perspective", Inter-University Center, Dubrovnik. 
Matějů, P. 1992. „Robert Erikson and John H. Goldthorpe: The Constant Flux. A Study of Class Mobility in Industrial Societies". Sociologický časopis 5 (28): 685-698.

Olneck, M., J. Crouse 1979. „The IQ Meritocracy Reconsidered: Cognitive Skill and Adult Success in the United States". American Journal of Education 88: 1-31.

Olneck, M. R., D. B. Bills 1980. „What Makes Sammy Run? An Empirical Assessment of the Bowles-Gintis Correspondence Theory“. American Journal of Education 89: 27-61.

Parsons, T. 1959. "The school class as a social system: some of its functions in American society". Harvard Educational Review 29: 297-318.

Rogoff, N. 1953. Recent Trends in Occupational Mobility. Glencoe: Free Press.

Rosen B. B., R. D'Andrade 1959. "The Psychological Origins of Achievement Motivation“. Sociometry 22: 185-218.

Sewell, W. H. 1961. "Social Class and Childhood Personality“. Sociometry 24: 340-356.

Sewell, W. H. 1963. "Some Recent Developments in Socialization Theory and Reseach". The Annals of the American Academy of Political and Social Science. Philadelphia, Vol. 349: 163-181.

Sewell, W. H., R. M. Hauser. 1972. "Causes and Consequences of Higher Education: Models of the Status Attainment Process". American Journal of Agricultural Economics 54: 851-861.

Sewell, W. H., R. M. Hauser 1975. Education, Occupation \& Earnings. New York: Academic Press.

Sewell, W. H., R. M. Hauser 1980. „The Wisconsin Longitudinal Study of Social and Psychological Factors in Aspirations and Achievements". Research in Sociology of Education and Socialization 1: 59-99.

Sewell, W. H., V. P. Shah 1967. "Socioeconomic Status, Inteligence, and the Attainment of Higher Education“. Sociology of Education 40: 1-23.

Sewell, W. H., V. P. Shah 1968a. "Social Class, Parental Encouragement, and Educational Aspirations“. American Journal of Sociology 73: 559-572.

Sewell, W. H., V. P. Shah 1968b. „Parents' Education and Children's Educational Aspirations and Achievements". American Sociological Review 33: 191-209.

Sewell, W. H., A. O. Haller, A. Portes 1969. „The Educational and Early Occupational Attainment Process". American Sociological Review 34: 82-92.

Sewell, W. H., A. O. Haller, G. W. Ohlendorf 1970. „The Educational and Early Occupational Status Attainment Process: Replication and Revision“. American Sociological Review 35: 1014-1027.

Sexton, Patricia C. 1961. Education and Income: Inequality of Opportunity in Our Public Schools. New York: Viking Press.

Sherif, M. 1935. "A study of some social factors in perception“. Archives of Psychology Number 187.

Schiller, B. 1970. „Stratified opportunities: The essence of the ,Vicious circle ${ }^{\prime \prime}$. American Journal of Sociology 76: 426-442.

Sorokin, P. 1927. Social Mobility. New York: Harper and Brothers.

Sorokin, P. 1959. Social and Cultural Mobility. New York: Free Press.

Šafáŕ, Z. 1972. „Model komplexní determinace profesionálního postavení". Pp. 277-308 in Sociální a profesionální mobilita pracujicino obyvatelstva ČSSR. Bratislava: ČSVUP.

Young, M. 1957. The Rise of Meritocracy. London: Penguin.

Young, M., J. Gibson 1963. „In search of an explanation of social mobility“. British Journal of Statistic Psychology 16: 27-36. 